\title{
IMPLEMENTASI TEKNIK ICE BREAKING UNTUK MENINGKATKAN AKTIVITAS BELAJAR DAN HASIL BELAJAR SISWA KELAS V MI MATHALIUL ULUM I MALANGAN PADEMAWU TIMUR PAMEKASAN
}

\author{
SITI ROHMAH \\ MI Mathaliul Ulum I Malangan Pademawu Timur Pamekasan \\ siti.rohmah980222@gmail.com
}

\begin{abstract}
Abstrak
Penelitian ini menggunakan pendekatan kualitatif dengan jenis deskriptif. Penelitian dilakukan di MI Mathaliul Ulum 1 Malangan Pademawu Timur Pamekasan, dengan subyek penelitian adalah siswa kelas V. Dan pengumpulan data dilakukan dengan mengadakan wawancara, observasi, dan dokumentasi.Hasil penelitian menunjukkan bahwa: pertama langkah-langkah teknik ice breaking ialah direncanakan dan dimasukkan dalam skenario pembelajaran pada awal pembelajaran, inti proses pembelajaran maupun akhir proses pembelajaran, ice breaking yang digunakan yaitu nyel-yel, games, tepuk tangan, dan tepuk harmoni. Kedua, keberhasilan teknik ice breaking untuk meningkatkan aktivitas belajar siswa yaitu dapat membuat siswa lebih kondusif dan aktif dalam mengikuti pembelajaran. Ketiga, keberhasilan teknik ice breaking untuk meningkatkan hasil belajar siswa, yaitu ketika guru memberikan atau menanyakan materi, pertanyaan, dan tugas siswa bisa menjawab dan mengerjakannya. Keempat, faktor pendukung seperti sarana dan prasarana, minat dan motivasi siswa, kesabaran guru dalam mengajar. Sedangkan faktor penghambatnya yaitu, sumber belajar masih minim, alat peraga atau media masih terbatas, dan juga siswa yang berbicara sendiri ketika pembelajaran berlangsung.
\end{abstract}

Kata Kunci: Teknik Ice Breaking, Aktivitas Belajar

\section{Abstract}

This research uses a qualitative approach with a descriptive type. The study was conducted at MI Mathaliul Ulum 1 Malangan Pademawu Timur Pamekasan, the research subjects were Grade V students. Data collection was carried out by conducting interviews, observations, and documentation. The results showed that: the first steps of the ice breaking technique were planned and included in the learning scenario at the beginning of the learning process, the core of the learning process and the end of the learning process, ice breaking used was yells, games, applause, and applause of harmony. Second, the success of the ice breaking technique to increase student learning activities is to make students more conducive and active in participating in learning. Third, the success of ice breaking techniques to improve student learning outcomes, namely when the teacher gives or asks material, questions, and assignments students can answer and do it. Fourth, supporting factors such as facilities and infrastructure, student interest and motivation, teacher patience in 
teaching. While the inhibiting factors are, learning resources are still minimal, teaching aids or media are still limited, and also students who speak for themselves when learning takes place.

Keywords: Ice Breaking Techniques, Learning Activities

\section{PENDAHULUAN}

Pendidikan adalah suatu proses dalam rangka mempengaruhi peserta didik supaya mampu menyesuaikan diri sebaik mungkin dengan lingkungannya, dan dengan demikian akan menimbulkan perubahan dalam dirinya yang memungkinkannya untuk berfungsi secara optimal dalam kehidupan masyarakat. Pada dasarnya pertumbuhan dan perkembangan peserta didik bergantung pada dua unsur yang saling mempengaruhi, yakni bakat yang dimiliki oleh peserta didik sejak lahir, dan lingkungan yang mempengaruhi hingga bakat itu tumbuh dan berkembang.

Berbicara Pendidikan tentunya tidak lepas dengan sistem pendidikan, yang keberadaanya masih transparan dilihat dari tatanan dan pemberlakuan kurikulum 2013, dan ini sudah saya rasakan, karena pemberlakuan kurikulum 2013 ini membutuhkan tenaga ekstra bagi guru-guru yang mengajar di sekolah dan sudah menerapkan kurikulum 2013 ini. Maka dari itu guru sekarang di tuntut untuk selalu terus melakukan pembaharuan karena di kurikulum 2013 ini guru sebagai fasilitator yang berperan memberikan pelayanan untuk memudahkan siswa dalam kegiatan proses pembelajaran. Pembaharuan yang dilakukan oleh guru ialah pembaharuan dalam menentukan sebuah model, strategi, pendekatan, dan teknik pembelajaran yang menempati posisi yang penting dalam suatu pembelajaran, karena keberhasilan sebuah pengajaran diantaranya ditentukan oleh penggunaan model, strategi, pendekatan, dan teknik yang tepat. Dan dengan begitu juga guru dapat mengetahui karakteristik dari setiap individu, sehingga guru menjadi lebih mudah dan mampu membawa peserta didiknya keranah pembelajaran yang sesuai tujuan pendidikan.

Mencapai hasil belajar tentunya tidak jarang menemukan beberapa peserta didik yang cenderung malas ketika suatu proses pembelajaran berlangsung, guru kadang di hadapkan dengan peserta didik yang ngantuk, capek, jenuh atau mungkin keadaan kelas sudak tidak terkontrol lagi (tidak kondusif), sehingga siswa tidak tertarik lagi untuk mendengarkan guru menyampaikan pelajaran, sehingga ini dapat mempengaruhi pencapaian hasil belajar.Menurut Roestiyah dalam buku "Strategi Belajar Mengajar" menyatakan bahwa didalam proses belajar mengajar, guru harus memiliki strategi, model, agar siswa dapat belajar secara efektif dan efesien, mengenai pada tujuan yang diharapkan. 
Salah satu langkah untuk memiliki strategi itu ialah harus menguasai teknik-teknik penyajian, atau biasanya disebut metode mengajar dalam pendidikan.

Dimana kenyataannya dalam proses pembelajaran lebih sering terjadi secara rutin dan berjalan biasa-biasa saja sesuai dengan prosedur dan jadwal yang telah ditentukan. Guru dalam melaksanakan pembelajaran lebih sering patuh terhadap rutinitas tersebut tanpa memperhatikan kondisi dan kebutuhan siswa, disamping itu guru juga jarang memperhatikan pengaruh pergantian mata pelajaran, apakah itu membuat siswa keletihan, ataupun kesulitan, kejenuhan, bahkan kejemuan akibat faktor pergantian mata pelajaran ataupun guru yang kurang menyenangkan dan itu semua jarang terpikirkan oleh guru.Sehingga disini menurut saya teknik yang cocok untuk memecahkan masalah diatas yang berkenaan dengan aktivitas belajar dan hasil belajar yaitu teknik ice breaking yang mana teknik ini mampu memusatkan perhatian siswa dengan memilih ice breaking apa yang tepat digunakan sesuai dengan kebutuhan.

Penerapan teknik ice breaking di MI Mathaliul Ulum ini memang ditujukan untuk kelas tinggi seperti kelas V MI Mathaliul Ulum 1 Malangan Pademawu Timur Pamekasan, karena pada kenyataanya di kelas-kelas tinggi ini memugkinkan terjadinya suatu masalah yang berkenaan dengan konsentrasi siswa pada saat pembelajaran tidak fokus, entah itu ngantuk, bosan, jenuh, dan lain-lain.

Dengan demikian seorang pendidik khususnya guru harus mampu menentukan suatu teknik yang dapat menciptakan situasi dan kondisi kelas yang kondusif serta pembelajaran akan lebih variatif, inovatif, dan kontruktif, sehingga siswa dapat mempelajari konsep yang dipelajarinya dengan pemberian arahan dan kontrol secara ketat dan tercapainya ketuntusan muatan akademik, keterampilan, dan juga meningkatnya percaya diri siswa.

Maka atas dasar fenomena diatas peneliti tertarik untuk meneliti "Implementasi Teknis Ice Breaking Untuk Meningkatkan Aktivitas Belajar Dan Hasil Belajar Siswa Kelas V MI Mathaliul Ulum 1 Malangan Pademawu Timur Pamekasan”

\section{METODE PENELITIAN}

Penelitian ini merupakan penelitian kualitatif yang lebih mengacu pada landasan filosofis fenomenologis, dimana unsur pemahaman mendalam dari sudut objek yang diteliti (subjek penelitian) merupakan hal yang utama, maka desain yang disusun pun harus memungkinkan teraplikasikan landasan tersebut secara optimal. Jenis penelitian ini adalah deskriptif. Secara Harfiah metode deskriptif adalah metode penelitian untuk membuat gambaran mengenai situasi atau kejadian, sehingga berkehendak mengadakan akumulasi data dasar, dimaksudkan untuk memperoleh gambaran yang benar dan jelas, sehingga dapat memberikan data yang sesuai dengan keadaan yang sebenarnya. 
Dan kehadiran peneliti disini yaitu untuk memperoleh pemahaman terhadap fenomena yang terjadi maka dalam penelitian ini, peneliti bertindak sebagai pengamat partisipan. Dimana peneliti sambil mengamati kegiatan yang dilakukan oleh guru dan peneliti juga ikut melakukan kegiatan dalam proses pembelajaran. Selain itu, kehadiran peneliti juga diketahui statusnya sebagai peneliti oleh informan.

Penelitian ini dilakukan di kelas V MI Mathaliul Ulum 1 Malangan Pademawu Timur Pamekasan. Sekolah ini terletak di Dusun Malangan Tengah Desa Pademawu Timur Kecamatan Pademawu Kabupaten Pamekasan. Peneliti memilih untuk melakukan penelitian di lokasi tersebut karena lokasi tersebut merupakan tempat peneliti sebagai guru PPL/ PM2, sehingga peneliti disini ingin meneliti bagaimana ketika teknik ice breaking ini diterapkan dan sejauh mana teknik Ice breaking ini diterapkan. Karena memang di Sekolah ini sudah menerapkan teknik ice breaking di sela-sela pembelajaran.

Sumber data dalam penelitian ini adalah manusia dan non manusia, dan data yang dibutuhkan dalam penelitian ini adalah data primer dan sekunder. Yang menjadi data manusia adalah guru kelas $\mathrm{V}$ karena merupakan orang yang berinteraksi langsung dengan peserta didik sehingga guru benar-benar tahu dengan kondisi peserta didik dan beliau juga yang menentukan model pembelajaran yang digunakan dalam proses pembelajaran, dan juga peserta didik kelas $\mathrm{V}$ yang berjumlah 10 orang, dengan jumlah siswi 6 orang dan siswa 4 orang, dan mereka adalah subjek dari proses belajar mengajar sehingga mereka yang merasakan berhasil tidaknya suatu proses pembelajaran. Sedangkan data non manusia adalah data-data guru, data siswa, jadwal pelajaran, dan juga dokumen-dokumen lainnya yang terkait.

Prosedur Pengumpulan data dalam penelitian kualitatif instrumen utamanya adalah peneliti sendiri, untuk mencari data dengan berinteraksi secara simbolik dengan subjek yang diteliti. Mengingat pentingnya pengumpulan data dalam penelitian, maka peneliti dituntut untuk menentukan metode pengumpulan data yang tepat dalam proses penelitian yang akan berlangsung.Untuk memperoleh data yang sesuai dengan permasalahan yang akan diteliti, maka prosedur pengumpulan data yang akan digunakan dalam penelitian ini adalah: observasi, wawancara, dan dokumentasi. Observasi digunakan untuk melihat yang ada dilapangan sehingga dengan observasi peneliti dapat mengumpulkan data yaitu secara mekanis sesuai yang diinginkan oleh peneliti. yang digunakan peneliti adalah observasi partisipan yaitu peneliti berpartisipasi dan terlibat langsung dalam kegiatan yang diamati. Wawancara digunakan untuk mengumpulkan data penelitian, peneliti menggunakan wawancara semi terstruktur karena peneliti akan menyusun terlebih dahulu hal-hal apa saja yang akan ditanyakan. Dokumentasi digunakan untuk pencarian data mengenai hal-hal yang berupa transkip, buku-buku yang relevan, surat kabar, laporan, dan foto. 
Analisis data adalah proses mencari dan menyusun secara sistematis data yang diperoleh dari hasil wawancara, catatan lapangan, dan bahan-bahan lain. Sehingga dapat dipahami, dan temuannya di informasikan kepada orang lain. Sedangkan analisis data kualitatif adalah upaya yang dilakukan dengan jalan bekerja dengan data, mengorganisasikan data, memilah-milahnya menjadi satuan yang dapat dikelola, mensintesiskannya, mencari dan menemukan pola, menemukan apa yang penting dan apa yang dipelajari, dan memutuskan apa yang dapat diceritakan kepada orang lain. Dalam penelitian ini, yang dianalisis adalah data yang diperoleh dari hasil wawancara, observasi, dan dokumentasi yang ada, langkah-langkahnya yaitu dengan 1) reduksi data, berarti merangkum memilih hal-hal yang pokok, memfokuskan pada hal-hal yeng penting, dicari tema dan polanya dengan reduksi data ini, peneliti perlu mengecek, dan mengedit. 2) Data display, dimana peneliti yang dapat memberikan peluang untuk mengambil kesimpulan. Peneliti disini menyusun data yang diperoleh dalam bentuk uraian singkat sehingga data dapat tersaji dengan baik tanpa ada data yang sudah tidak dibutuhkan. 3) Penarikan kesimpulan, atau interaktif, hipotesis atau teori. Setelah semua data terkumpul dilakukanlah pemilihan secara selektif disesuaikan dengan permasalahan yang diangkat dalam penelitian ini. Dan proses verifikasi dalam hal ini peneliti meninjau ulang terhadap catatan lapangan, dari mereduksi data, penyajian data kemudian penarikan kesimpulan yang benar-benar valid sesuai dengan bukti-bukti yang mendukung.

Untuk mengetahui apakah data yang diperoleh dari penelitian ini valid dan bisa di pertanggungjawabkan, maka peneliti berusaha mengeceknya agar tidak sia-sia. Dalam mengukur validitas data temuan digunakan teknis sebagai berikut: 1) Perpanjangan keikutsertaan, Perpanjangan keikutsertaan yang digunakan oleh peneliti digunakan apabila data yang dibutuhkan belum lengkap, maka peneliti harus memperpanjang lagi penelitian di lapangan untuk mencapai hasil yang sangat valid dan benar. 2) Ketekunan peneliti, Ketekunan peneliti disini yaitu mengecek kembali hasil penelitiannya apakah benar atau ada yang salah, ketika mengecek kembali ternyata ada kesalahan, maka peneliti bisa memperbaiki data tersebut sehingga peneliti dapat memberikan deskripsi data yang akurat dan sistematis tentang apa yang diamati. Peneliti disini melakukan pengamatan secara cermat dan mendalam untuk mendapatkan kepastian data, oeh karena itu penelitipun membaca berbagai referensi dari berbagai sumber dan hasil penelitian yang berkaitan dengan temuan peneliti. 3) Triangulasi, Adapun dalam penelitian ini yang digunakan adalah triangulasi sumber dan waktu, peneliti membandingkan dan mengecek balik derajat kepercayaan atau informasi yang diperoleh melalui waktu dan alat yang berbeda. Dalam hal ini berarti data yang di peroleh dari hasil wawancara oleh pihak peneliti di cek, kemudian dibandingkan dan diperkuat dengan hasil observasi dan dokumentasi. Atau jika 
perlu demi menjaga keabsahan data, ada kemungkinan peneliti akan kembali mewawancarai informan pada waktu yang berbeda.

Adapun tahap-tahap penelitian yang dilakukan oleh peneliti untuk mengetahui obyek penelitian secara sistematis sebagai berikut: 1) Pra- penelitian, membuat judul, menentukan konteks penelitian, memilih lokasi penelitian, membuat fokus penelitian, membuat usulan proposal, penelitian, mengurus izin penelitian, menjajaki dan menilai keadaan lokasi penelitian, mempersiapkan perlengkapan penelitian. 2) Pelaksanaan penelitian, memahami latar belakang penelitian, menyiapkan fisik dan mental diri, melakukan penelitian, mengumpulkan data yang dibutuhkan baik yang primer ataupun sekunder. Setelah data terkumpul, maka dilakukan analisis data yang telah diperoleh. 3) Pelaporan, Dalam menyusun laporan peneliti menulis kerangka dan isi laporan hasil penelitian, adapun mekanisme yang diambil dalam penyusunan laporan disesuikan dengan buku pedoman penulisan karya ilmiah IAIN Madura.

\section{HASIL PENELITIAN}

1. Langkah-langkahTeknik Ice Breakingyang Digunakan Guru untuk Meningkatkan Aktivitas Belajar dan Hasil Belajar Siswa Kelas V MI Mathaliul Ulum 1 Malangan Pademawu Timur Pamekasan

Pemilihan sebuah model dan teknik pembelajaran sangatlah penting dalam proses belajar mengajar yang dikarenakan model dan teknik pembelajaran banyak sekali macamnya. Mungkin suatu model dengan teknik tertentu dalam pembelajaran sangatlah efektif digunakan pada mata pelajaran tertentu, akan tetapi belum tentu efektif diterapkan untuk mata pelajaran lainnya. Oleh sebab itu, agar memperoleh model dan teknik pembelajaran yang tepat, maka diperlukan kepandaian seorang guru dalam menerapkanmodel dan teknik pembelajaran yang nantinya bisa membawa anak didiknya belajar sesuai dengan apa yang di inginkannya. Seperti halnya guru kelas V MI Mathaliul Ulum 1 Malangan Pademawu Timur yang menerapkan teknik ice breaking untuk meningkatkan aktivitas belajar dan hasil belajar siswa.

Sebagaimana dalam buku $\mathrm{M}$ Said, yang berjudul $80+$ ice breakergames, bahwasanya ice breaker adalah permainan atau kegiatan yang berfungsi untuk mengubah suasana kebekuan dalam kelompok. Ice breaker yang dipilih, yang mungkin bersifat spontan atau tanpa persiapan khusus. Ice breaker bisa digunakan baik untuk kelompok kecil maupun kelompok besar. Maka dari itu, untuk memulai suatu traning, pembelajaran, permainan, dinamika kelompok. Ice breakeryang dipilih atau yang digunakan harus benar-benar relevan dan tepat guna.Dan teknik ice breaking yang digunakan oleh guru MI Matahaliul Ulum 1 Malangan Pademawu Timur untuk meningkatkan aktivitas belajar dan hasil belajar siswa kelas V ini bervariasi sesuai dengan 
situasi dan kondisi pada saat proses pembelajaran berlangsung dan ini tentunya sudah senada dengan pendapatnya M Said di atas, bahwasanya ice breaking yang digunakan harus relevan dan tepat guna sesuai dengan kebutuhan pada saat pembelajaran. Dan teknik ini juga memiliki prinsip tertentu dalam penerapannya yaitu, sebagai penyeimbang antara otak kanan dan otak kiri, dilakukan ketika jeda materi saat mulai muncul kejenuhan, dan bentuk pendekatan kepada peserta didik.

langkah-langkah teknik ice breaking yang digunakan guru untuk meningkatkan aktivitas belajar dan hasil belajar siswa yaitu dengan melihat situasi kondisi, karena dalam penerapan ice breaking dalam pembelajaran dapat dilakukan pada awal pembelajaran, pada inti proses pembelajaran maupun pada akhir proses pembelajaran. Sehingga ice breaking yang digunakan guru untuk meningkatkan aktivitas belajar dan hasil belajar peserta didik diantaranya ialah:

a. Yel-yel

Yel-yel ini sangat efektif dalam menyiapkan aspek psikologi siswa didik untuk siap mengikuti pelajaran, terutama pada jam-jam awal pembelajaran. yel-yel juga sangat efektif membangun kekompakan dan kerja sama dalam kelompok. Dan yel-yel disini ada 2 model yaitu:

1) Model mono yel

Model yel-yel yang di ucapkan sendiri oleh peserta didik baik secara individual maupun kelompok secara satu arah mulai awal hingga selesai yel di ucapkan. Yel-yel ini biasanya digunakan oleh siswa atau kelompok sendiri seperti ketika akan melaksanakan suatu tugas atau maju mempresentasikan hasil kerja. Contohnya: mana dimana kelompok paling hebat, kelompok paling hebat adalah kelompok venus. Mana dimana kelompok paling dahsyat, kelompok paling dahsyat adalah kelompok venus.

2) Model interaktif yel

Interaktif yel yaitu model yel-yel yang diucapkan secara bersahutan antara guru dengan siswa didik atau antara siswa didik dengan siswa didik lainnya. Yel-yel yang sering dipakai bentuk ini adaah salam sapa untuk memusatkan perhatian. Misalnya ketika guru mengucapkan HALO, maka siswa menjawab dengan kata HAI. Juga sebaliknya jika guru mengucapkan kata HAI, maka siswa menjawab dengan kata HALO.

b. Tepuk tangan

Jenis ice breaker ini adalah jenis paling sering digunakan oleh para pendidik. Dalam kepramukaan tepuk tangan sangat populer dimanfaatkan oleh para pendidikan dengan segala variasinya, mulai dari tepuk pramuka, tepuk setan, tepuk sambel, dan sebagainya. Teknik tepuk merupakan teknik ice breaker yang paling mudah, karena tidak memerukan persiapan yang membutuhkan banyak waktu.

c. Tepuk harmoni 
Dimana tepuk harmoni disini siswa diajak berdiri dalam bentuk lingkaran, siswa diminta bertepuk tangan panjang, sampai tercipta bunyi yang mempunyai harmoni, jika tidak berhasil, beri aba-aba tepuk tangan pramuka.

\section{d. Games}

Games atau permainan adalah jenis ice breaker yang paling membuat siswa heboh. Siswa akan muncul semangat baru yang lebih saat melakukan permainan. Rasa ngantuk menjadi hilang dan sikap apatis spontan berubah menjadi aktif, melalui permainan suasana menjadi cair sehingga kondisi belajar menjadi kondusif, dengan permainan juga dapat membangun konsentrasi anak untuk dapat berpikir, bertindak lebih baik dan lebih efektif. Dengan kegiatan permainan konsentrasi siswa akan kembali terfokus sehingga materi pelajaran akan lebih mudah di cerna.

\section{Keberhasilan Teknik Ice Breakinguntuk Meningkatkan Aktivitas Belajar Siswa Kelas} V MI Mathaliul Ulum 1 Malangan Pademawu Timur Pamekasan

Melihat pengimplementasian teknik ice breaking untuk meningkatkan aktivitas belajar siswa kelas V MI Mathaliul Ulum 1 Malangan Pademawu Timur Pamekasan ini perlu adanya suatu proses dan tahapan-tahapan. Dimana tahapan-tahapan tersebut dapat membawa perubahan yang diharapkan dapat meningkatkan suatu pembelajaran yang diinginkan seperti halnya penerapan sebuah model dan teknik pembelajaran, dimana model pembelajaran adalah sebuah rangkaian penyajian materi ajar yang meliputi segala aspek sebelum sedang dan sesudah pembelajaran yang dilakukan guru serta segala fasilitas yang terkait yang digunakan secara langsung atau tidak langsung. Sedangkan teknik pembelajaran adalah implementasi dari metode pembelajaran yang secara nyata berlangsung di dalam kelas tempat terjadinya proses pembelajaran. Ini yang besar harapannya untuk dapat meningkatkan aktivitas belajar yang terjadi di dalam kelas, dan tentunya perlu suatu kekreatifan guru untuk menemukan seperti apa tipe belajar anak dan seperti apa gaya belajar anak yang di inginkan. Dan juga seorang pendidik hendaknya menyadari bahwa peserta didik memiliki berbagai cara belajar. beberapa peserta didik paling baik belajar dengan cara melihat orang lain melakukannya. Mereka lebih senang mencatat apa yang pengajar katakan. Selama pelajaran, mereka biasanya tenang dan jarang teganggu oleh suara.

Hal ini juga dikemukakan oleh Dierich dalam buku konsep strategi belajar, bahwasanya aktivitas belajar dibagi ke dalam delapan kelompok, diantaranya kegiatankegiatan visual yaitu, membaca, melihat gambar-gambar, mengamati eksperimen, demonstrasi, pemeran, dan mengamati orang lain bekerja atau bermain. Sehingga mereka betul-betul ada pada kemampuannya untuk mendengar dan mengingat. Sehingga ini juga dikatakan jenis aktivitas belajar menghafal yang merupakan aktivitas menanamkan suatu 
materi verbal melalui proses mental dan menyimpannya dalam ingatan, sehingga dapat diproduksi kembali ke alam sadar ketika diperlukan.

Aktivitas belajar dalam pembelajaran itu sendiri memiiki manfaat tertentu antara lain:

a. Siswa mencari pengalaman sendiri dan langsung mengalami sendiri:

b. Berbuat sendiri akan mengembangkan seluruh aspek pribadi siswa

c. Memupuk kerja sama yanh harmonis dikalangan para siswa yang pada gilirannya dapat memperlancar kerja kelompok.

d. Siswa belajar dan bekerja berdasarkan minat dan kemampuan sendiri sehingga sangat bermanfaat dalam rangka pelayanan perbedaa individual.

e. Memupuk disiplin belajar dan suasana belajar yang demokratis dan kekeluargaan, musyawarah dan mufakat.

f. Membina dan memupuk kerja sama antara sekoah dan masyarakat dan hubungan antara guru dan orang tua siswa, yang bermanfaat dalam pendidikan siswa.

g. Pembelajaran dan belajar dilaksanakan secara realistik dan konkrit, sehingga mengembangkan pemahaman dan berpikir kritis serta menghindarkan verbalisme.

h. Pembelajaran dan kegiatan belajar menjadi hidup sebagaimana mana halnya kehidupan dalam masyarakat yang penuh dinamika.

Dimana dalam penerapan teknik ice breaking pastilah sedikit banyak menghasilkan perubahan dalam aktivitas belajar siswa, sebagaimana menurut Nanang Hanafiah dan Cucu Suhana dalam buku"Konsep Strategi Pembelajaran" bahwasanya, aktivitas dalam belajar dapat memberikan nilai tambah dan manfaat (value)salah satunya peserta didik belajar dengan menurut minat dan kemampuannya.Dimana minat belajar secara bahasa terdiri dari dua suku kata yaitu minat dan belajar. Dimana minat merupakan kecenderungan hati yang tinggi terhadap sesuatu, gairah atau keinginan. Sedangkan belajar berarti berusaha memperoleh kepandaian atau ilmu maka dapat dirumuskan bahwa secara bahasa adalah keinginan hati yang tinggi untuk berusaha memporoleh kepandaian atau ilmu.

Keberhasilan dalam meningkatkan aktivitas belajar yang di capai oleh siswa/siswi kelas V MI Mathaliul Ulum 1 Malangan ini terlihat pada hal-hal diantaranya:

a. Peserta didik kelas V sudah mulai memperhatikan, menyimak/mendengarkan dan menulis ketika guru menerangkan suatu materi maupun berdiskusi.

Seperti halnya menurut Puger Honggowiyono dalam bukunya "Pertumbuhan dan Perkembangan Peserta Didik", salah satunya ialah ciri-ciri belajar auditorial, dimana ciri belajar auditorial disini belajar dengan mendengarkan dan mengingat apa yang 
didiskusikan dari apa yang dilihat. Sehingga dapat peneliti lihat bahwasanya sebagian besar peserta didik kelas $\mathrm{V}$ ciri belajarnya yaitu auditorial (belajar dengan cara mendengar). Juga di jelaskan dalam buku "Revolusi Belajar", bahwasanya tipe belajar auditorial lebih mudah mencerna, mengolah, dan menyampaikan informasi dengan jalan mendengarkan secara langsung. Mereka cenderung belajar atau menerima informasi dengan mendengarkan atau secara lisan. Dan ini sudah jelas dari peningkatan peserta didik yang semula jarang memperhatikan, sekarang sudah mulai memperhatikan. Dan ini juga peneliti lihat ketika guru kelas $\mathrm{V}$ mengajar, pendekatan guru terhadap peserta didik terjalin dengan baik, guru mengajak bernyanyi disela-sela pembelajaran (ice breaking), bercerita, dan bermain. Sehingga membuat peserta didik lebih aktif dalam mengikuti pembelajaran.

b. Kekondusifan peserta didik itu sendiri, yang biasanya main-main, bicara sendiri, sekarang sudah memusatkan perhatiannya terhadap guru pengajar,dan juga antusias mereka pada saat menerima materi juga beda dari sebelumnya, mereka yang enggan melakukan kegiatan-kegiatan belajar seperti, kegiatan visual, kegiatan lisan, dan belajar berpikir. Dan Mereka sudah mulai termotivasi sedikit demi sedikit, sudah mulai mengerjakan soal sendiri dengan nalar mereka.

Sebagaimana menurut Hendra Surya dalam buku "menjadi Manusia Pembelajar" bahwasanya motivasi adalah dorongan atau usaha untuk mewujudkan perbuatan dalam bentuk aktivitas mencapai kebutuhan atau tujuan tertentu. Ketiga komponen minat, perhatian, dan motivasi merupakan faktor-faktor yang ada pada setiap orang untuk melakukan aktivitas tertentu. dan dalam aktivitas belajar, jika ketiga komponen seperti halnya diatas yang sudah dijelaskan yaitu minat, perhatian, dan motivasi tidak optimal, maka akan mengalami kesulitan melakukan konsentrasi belajar. dan dengan ini sudah jelas bahwasanya ketiga komponen seperti minat, perhatian, dan motivasi peserta didik khususnya kelas V sudah optimal, karana mereka sudah terdorong untuk melakukan aktivitas yang berkenaan dengan pembelajaran dan sudah konsentrasi dalam belajar.

c. Peserta didik merasa senang dan terhibur dengan penerapan teknik ice breakingini, yang semula biasa-biasa saja mengikuti pelajaran, sekarang mereka lebih bisa memahami dan mengerti apa yang sudah guru jelaskan di depan kelas. Dan ini berkenaan langsung dengan cara bagaimana guru berinteraksi langsung dengan peserta didik, khususnya dalam menjelaskan suatu materi.

Seperti halnya dalam buku Marno yang berjudul "Strategi, Metode, dan Teknik Mengajar", dijelaskan bahwasanya menjelaskan adalah menuturkan secara lisan mengenai suatu bahan pelajaran yang disampaikan secara sistematis dan terencana sehingga memudahkan siswa untuk memahami bahan pelajaran. Hal ini sudah menyadari akan banyaknya peristiwa belajar mengajar yang menuntut guru untuk dapat menjelaskan, maka 
keterampilan menjelaskan merupakan dasar keterampilan mengajar yang harus dikuasai oleh guru khusunya guru kelas $\mathrm{V}$.

d. Dan peserta didik pun tidak merasakan bosan, ngantuk, capek, dan lain-lain pada saat pergantian jam pelajaran. Karena mereka begitu bersemangat dan antusias mengikuti pelajaran.

3. Keberhasilan Teknik Ice Breakinguntuk Meningkatkan Hasil Belajar Siswa Kelas V MI Mathaliul Ulum 1 Malangan Pademawu Timur Pamekasan

Berbeda dari keberhasilan pengimplementasian teknik ice breaking untuk meningkatkan aktifitas belajar siswa, pengimplementasian teknik ice breaking untuk meningkatkan hasil belajar siswa kelas V MI Mathaliul Ulum 1 Malangan Pademawu Timur Pamekasanyang di capai oleh siswa/siswi kelas V MI Mathaliul Ulum 1 Malangan ini terlihat diantaranya:

a. Ketika guru kelas $\mathrm{V}$ memberikan atau menanyakan materi yang telah di jelaskan (evaluasi) siswa sudah bisa menjawab, dan juga ketika guru memberikan tugas individu atau kelompok mereka bisa mengerjakannya, tanpa melihat ke temannya yang lain.

Dalam kaitannya dengan proses pembelajaran, ada beberapa hal yang harus dilakukan oleh seorang guru agar mencapai hasil maksimal, dimuat dalam buku Ngainun Naim yang salah satunya menjelaskan bahwasanya guru memberikan feedback(umpan balik) yaitu sebuah proses pembelajaran akan senantiasa berada dalam situasi yang ideal jika terus menerus terjadi umpan balik. Adanya umpan balik berfungsi sebagai sarana untuk membantu memelihara minat dan antusiasme siswa dalam melaksanakan pembelajaran. ${ }^{1}$ hal ini dapat dilakukan melalui evaluasi, untuk bentuk umpan balik sendiri dapat dimodifikasi sedemikian rupa secara kreatif sesuai dengan kondisi kelas yang diajarnya. Dan bapak Subhan disini tentunya memberikan umpan balik dengan cara mengevaluasi atau menanyakan kembali materi yang sudah dijelaskan dalam pertemuan yang sebelumnya.

b. Dan pada pertemuan berikutnya, seperti biasa guru melakukan evaluasi berupa pertanyaan terlebih dahulu mengenai materi yang sebelumnya, dan ternyata siswa/siswi masih bisa mengingat materi yang sudahdijelaskan sebelumnya.

Seperti yang sudah dikatakan oleh Kartono dalam buku Psikologi Pendidikan bahwa ingatan atau yang dikenal dengan memori ialah kemampuan untuk mencamkan, menyimpan dan memproduksi kembali hal-hal yang pernah diketahui. Jadi dengan begitu peserta didik kelas $\mathrm{V}$ menurut peneliti sudah mampu mengingat karena mereka sudah memberikan jawaban ketika evaluasi pembelajaran, dan dari sinilah keberhasilan model

${ }^{1}$ Ngainun Naim, Menjadi Guru Inspiratif (Yogyakarta: Pustaka Belajar, 2016), hlm. 26. 
pembelajaran langsung dengan teknik ice breaking untuk meningkatkan hasil belajar siswa sudah nampak jelas dari perubahan-perubahan yang ada.

c. Sikap, akhlak dan kepribadiaannya lebih berkembang atau meningkat, dari yang semula jarang menghargai guru di depan untuk menjelaskan materi, sekarang sudah mulai fokus mendengarkan.

Dan yang semula mereka membuat guru kelas marah, sekarang mereka lebih sopan dengan mengikuti perintah guru. Seperti halnya pengertian hasil belajar menurut bapak Subhan selaku guru kelas V memang kebanyakan identik dengan nilai, nilai tambah yang di dapat oleh peserta didik. Tapi menurut beliau, nilai tambah itu ialah ketika peserta didik dapat mempertahankan akhlak dan kepribadiaannya lebih berkembang atau meningkat, dari yang semula jarang menghargai guru di depan menjelaskan materi, sekarang sudah mulai fokus mendengarkan.

d. Dan peserta didik aktif dan mudah menjawab pertanyaan dari bapak Subhan, contohnya materi mengenai "iklan" dengan bermain peran, disitu banyak sekali permainan, lagu-lagu yang mengasah peserta didik giat belajar, sehingga dibentuklah kelompok dengan membuat iklan dan langsung ke depan kelas untuk mendemonstrasikan hasil kerja kelompok, dan Alhamdulillah peneliti lihat adekadek bisa berani menjawab dan mengerjakan sesuai dengan kemauan bapak Subhan selaku guru kelas V.

e. Juga dilihat dari pak Subhan ketika memberikan tugas individu dengan pemberian waktu yang sedikit, sehingga siswa/siswi harus menjawab, dan Alhamdulillah mereka bisa mengerjakan dan tepat waktu. Dilihat dari mereka yang grasak-grusuk menjawab, dan juga ketika pak Subhan memberikan PR mereka sudah mengerjakannya dan maju kedepan kelas, meskipun sebagian besar dari mereka yang masih saja kurang teliti dalam mengerjakannya.

Seperti yang dikemukakan oleh Wahidmurni, dkk bahwa peserta didik dikatakan berhasil dalam belajar jika pada diri mereka telah terjadi perubahan dari minimal salah satu aspek, contoh perubahan dalam aspek kemampuan bepikir misalnya dapat terjadi jika terjadi perubahan dari tidak tahu menjadi tahu, atau perubahan dari tidak paham menjadi paham dan seterusnya. Contoh aspek sikap, misalnya dari sikap yang buruk menjadi sikap yang baik atau dari sikap yang buruk menjadi sikap yang baik, atau dari semula bersikap tidak sopan menjadi sikap yang sopan. Contoh perubahan dalam aspek ketrampilan misalnya, dari tidak dapat melakukan wudhu menjadi terampil berwudhu dari tidak terampil melukis menjadi terampil melukis dan setersnya.

Sehingga, dengan adanya ini peneliti menyimpulkan bahwasanya model pembelajaran langsung dengan teknik ice breaking untuk meningkatkan hasil belajar siswa 
itu berhasil dan lebih meningkat dilihat dari perubahan-perubahan yang semula tidak mengerjakan tugas sekolah, justru sekarang membuat siswa giat belajar dan mengerjakan tugas sesuai perintah guru.

4. Faktor Pendukung dan Penghambat TerlaksananyaTeknik IceBreakinguntuk Meningkatkan Aktivitas Belajar dan hasil Belajar Siswa Kelas V MI Mathaliul Ulum 1 Malangan Pademawu Timur Pamekasan

Disetiap pembelajaran pastilah ada faktor yang dapat membuat suatu teknik pembelajaran terdorong untuk diterapkan ataupun menjadi gagal di terapkan, baik itu faktor pendukung maupun faktor penghambat yang mempunyai kriteria masing-masing, begitu juga dengan implementasi model pembelajaran langsung dengan teknik ice breaking untuk meningkatkan aktivitas belajar dan hasil belajar siswa kelas V MI Mathaliul Ulum 1 Malangan Pademawu Pamekasan yang di dalamnya juga terdapat faktor pendukung dan penghambat.

Sebagaimana hasil wawancara yang dilakukan oleh peneliti dengan bapak Subhan selaku guru kelas V MI Mathaliul Ulum 1 Malangan Pademawu Timur Pamekasan beliau mengemukakan bahwasanya ada beberapa poin yang menjadi faktor pendukung terlaksananya model pembelajaran langsung dengan teknik ice breakingini salah satunya yaitu:

a. Sarana dan prasarana yang disediakan oleh sekolah.

Sarana dan prasana pendidikan adalah sebuah benda bergerak dan tidak bergerak dibutuhkan untuk menunjang penyelenggaraan kegiatan belajar mengajar, baik secara langsung maupun tidak langsung. Sarana dan prasarana ini digunakan agar tujuan pendidikan di sekolah dapat tercapai dengan efektif dan efesien.Dan tidak dapat dipungkiri lagi bahwa sarana dan prasarana sangat mempengaruhi kemampuan siswa dalam belajar, mengingat pentingnya sarana prasarana dalam kegiatan pembelajaran, maka peserta didik, guru dan sekolah akan terkait secara langsung. Peserta didik akan lebih terbantu dengan dukungan sarana dan prasarana pembelajaran. dan sarana yang ada di sekolah MI Mathaliul Ulum I Malangan Pademawu Timur yaitu: gedung, ruangan belajar/kelas, alatalat atau media pendidikan, meja, kursi, dan perpustakaan. Sedangkan prasarana yang menunjang jalannya pendidikan, seperti halaman, taman sekolah, dan jalan menuju sekolah.

b. Semangat dan minat siswa itu sendiri.

Semangat dan minat dalam belajar timbulah sebuah motivasi atau dorongan dari dalam siswa itu sendiri. Seperti yang dikatakan Slameto dalam buku "Revolusi Belajar" bahwasanya minat adalah kecenderungan yang tetap untuk memperhatikan dan mengenang beberapa kegiatan. Sehingga minat sangat berpengaruh terhadap proses dan hasil belajar 
siswa. Jika bahan yang dipelajari tidak sesuai dengan minat seseorang, tentunya ia tidak akan begitu bersemangat dalam belajar. Hal ini akan membawa pengaruh negatif terhadap hasil belajarnya kemudian. Berbeda halnya dengan seseorang yang belajar tentang bahan pelajarn yang sesuai dengan minatnya. Tentu saja ia akan sangat bersemangat dalam proses belajar sehingga hal ini akan membawa pengaruh positif bagi hasil belajarnya.

c. Kekreatifan guru

Kekreatifan guru dalam memilih dan memilah model, strategi, pendekatan, serta teknik yang cocok untuk diterapkan kepada peserta didik itu sangatlah penting, sehingga dapat mengetahui pola belajar seperti apakah yang diinginkan oleh peserta didik.Karena kunci keberhasilan yang di dapat oleh peserta didik ialah dari guru yang senantiasa memberikan dan menerapkan inovasi pendidikan yang terbaru bagi peserta didiknya, dan juga seorang pendidik atau guru harus memiliki kompetensi guru yang meliputi, kompetensi pedagogik, kompetensi kepribadian, kompetensi sosial, dan kompetensi profesional yang diperoleh melalui pendidikan profesi. Sehingga sangat jelas disini bahwasanya seorang guru harus berkompeten terutama dalam merencanakan programprogram pembelajaran yang terbaru, karena kompetensi pedagogik guru berkaitan dengan kemampuan guru untuk mengelola program pembelajaran didalamnya mencangkup kemampuan untuk mengeloborasi kemampuan peserta didik, merencanakan program pembelajaran, melaksanakan program pembelajaran, dan mengevaluasi program pembelajaran.

d. Dan yang terakhir karena faktor lingkungan.

Hal yang dapat menunjang optimalisasi proses dan hasil belajar salah satunya adalah dengan menciptakan lingkungan belajar yang nyaman. Dalam sekolah misalnya, paling tidak seluruh warga sekolah senantiasa menciptakan situasi, kondisi, serta suasana yang baik, aman, dan nyaman. Lingkungan sekolah yang baik tentunya akan membuat semua warga sekolah terutama peserta didik akan betah di sekolah.

Adapun faktor penghambat terlaksananya model pembelajaran langsung dengan teknik ice breaking yang diterapkan oleh bapak Subhan dalam meningkatkan aktivitas belajar dan hasil belajar siswa kelas V salah satunya yaitu:

a. Sumber belajar diantaranya buku-buku yang di pakai yaitu buku tematik (buku guru dan buku siswa), yang kurang memadai

b. Alat peraga atau media yang bisa digunakan dalam simulasi pembelajaran, masih terbatas.

c. Emosi yang disebabkan dari siswa itu sendiri, yang mana emosi berpengaruh besar pada kualitas dan kuantitas belajar. seperti menurut William James mendefinisikan emosi sebagai keadaan budi rohani yang menampakkan dirinya dengan suatu perubahan yang jelas pada tubuh. Sehingga peneliti disini dapat menyimpulkan 
bahwasanya emosi merupakan suatu perasaan yang dimiliki oleh setiap insan yang terjadi secara sadar atau tidak sadar, sehingga keberadaanya berubah-rubah sesuai dengan suasana hati atau perasaan seseorang.

\section{KESIMPULAN}

Berdasarkan temuan dan pembahasan hasil penelitian di atas. sebagaimana dibahas pada bab sebelumnya dapat disimpulkan berikut ini:

Berdasarkan pada temuan dan pembahasan hasil penelitian di atas dan fenomena yang ada sebagai hasil penelitian dari "Implementasi Teknik Ice Breaking untuk Meningkatkan Aktivitas Belajar dan Hasil Belajar Siswa MI Mathaliul Ulum 1 Malangan Pademawu Timur Pamekasan" dapat peneliti simpulkan bahwasanya langkah-langkah ice breaking yang digunakan guru untuk meningkatkan aktivitas belajar dan hasil belajar siswa kelas V MI Mathaliul Ulum 1 Malangan Pademawu Timur Pamekasan yang direncanakan dan dimasukkan dalam skenario pembelajaran. yang telah ditetapkan. Ice breaking dalam pembelajaran dapat lakukan pada awal pembelajaran, pada inti proses pembelajaran maupun pada akhir proses pembelajaran sedangkan ice breaking yang digunakan guru yaitu yel-yel, Games (permainan), Tepuk tangan, dan tepuk harmoni. Yang tentunya dapat membuat peserta didik lebih aktif dalam mengikuti pembelajaran.

Keberhasilan teknik ice breaking untuk meningkatkan aktivitas belajar siswa kelas V MI Mathaliul Ulum 1 Malangan Pademawu Timur Pamekasan juga dapat dilihat ketika peserta didik memperhatikan, mendengarkan, dan menyimak guru, melakukan kegiatankegiatan yang berkenaan dengan aktivitas belajar, yang semula bermain-main sendiri sekarang justru fokus untuk memperhatikan guru menjelaskan materi.

Berbeda dengan keberhasilan teknik ice breaking untuk meningkatkan aktivitas belajar siswa kelas V MI Mathaliul Ulum 1 Malangan Pademawu Timur Pamekasan dapat dilihat dari ketika peserta didik mampu menjawab pertanyaan-pertanyaan dari guru, ketika guru mengevaluasi pembelajaran mereka begitu antusias untuk menjawab. Ketika guru memberikan atau menanyakan materi, pertanyaan, dan tugas siswa bisa menjawab dan mengerjakannya.

Sedangkan faktor pendukung dan penghambat terlaksananya teknik ice breaking untuk meningkatkan aktivitas belajar dan hasil belajar siswa kelas V MI Mathaliul Ulum 1 Malangan Pademawu Timur Pamekasan ialah, ketelatenan guru, sarana dan prasarana, dan juga kekreatifan guru dalam memilih model dan teknik pembelajaran. Faktor penghambat ialah, sumber belajar dan alat peraga yang masih minim, emosi yang diciptakan oleh peserta didik sendiri. Sehingga itu dapat mempengaruhi proses belajar mengajar. 


\section{DAFTAR PUSTAKA}

Abu Ahmadi dan Joko Tri Prasetya. Strategi Belajar Mengajar. Bandung: Pustaka Setia, 1997.

Afi Parnawi, Psikologi Belajar. Sleman: Deepublish, 2019.

Aryfiani Dwi Lestari, "Peningkatan Aktivitas Belajar IPA dengan Model Discovery Berbantuan Media Gambar di Kelas V SD Negeri Pakis 1 Magelang", Jurnal Konvergensi, Vol. VI. Januari 2019.

Aunurrahman, Belajar dan Pembelajaran. Bandung: Alfabeta, 2009.

Dimyati dan Mudjiono, Belajar dan Pembelajaran. Jakarta: Rineka Cipta, 2013.

Emi Mursidawati, "Implementasi Ice Breaking dalam Pembelajaran Bahasa Arab di Lembaga Boarding Scholl SMP IT Ihsanul Fikri Mungkid Magelang”, Thesis, hlm. 25.

Halid hanafi dan muzakkir, Profesionalisme Guru dalam Pengelolaan Kegiatan Pembelajaran disekolah (yogyakarta: cv budi utama, 2019.

Komaruddin hidayat, Active learning 101 Pembelajaran Aktif.yogyakarta: Pustaka Insan Madani, 2009.

M said, 80+ ice breaker games. Yogyakarta: cv andi offset, 2010.

Moch Ilham Sidik dan Hendri Winata, "Meningkatkan Hasi Belajar Siswa Melalui Penerapan Model Pembelajaran Direct Instruction".

Nanang Hanafiah dan Cucu Suhana.Konsep Strategi Pembelajaran. Bandung: PT Refika Aditama, 2012.

Ngainun Naim, Menjadi Guru Inspiratif. Yogyakarta: Pustaka Belajar, 2016.

Nyanyu Khodijah, Psikologi Pendidikan. Jakarta: PT Raja Grafindo Persada, 2014.

Oemar Hamalik, Kurikulum dan Pembelajaran. Jakarta: Remaja Rosdakarya, 2012.

Rahmat Putra Yudha, Motivasi Berprestasi dan Disiplin Peserta Didik. Pontianak: Yudha English Gallery, 2018.

Roestiyah, Strategi Belajar Mengajar. Jakarta: PT Rineka Cipta, 2008.

Rohiat, Manajemen Sekolah. Bandung: PT. Refika Aditama, 2012.

Rusman, Belajar dan Pembelajaran Berorientasi Standar Proses Pendidikan. Jakarta: Kencana, 2017.

Sunarto, Ice Breaker Dalam Pembelajaran Aktif. Surakarta: Cakrawala Media, 2012

Suyono dan Hariyanto, Belajar dan Pembelajaran. Bandung; PT Remaja Rosdakarya, 2016 Syaiful Bahri Djamarah,Psikologi Belajar. Jakarta: Rineka Cipta, 2011.

Sutrisno, Tri. 2019. Pengaruh Pembelajaran Berbasis Masalah (Problem Based Learning) Terhadap Kemampuan Berpikir Kritis Siswa pada Mata Pelajaran PKn Kelas VI di SDN Kota Sumenep.ELSE (Elementary School Education Journal): Jurnal Pendidikan dan Pembelajaran Sekolah Dasar. Volume 3 Jilid 2. Hal. 98-110 
S iti R ohmah

Implementasi T eknik Ice B reaking untuk M eningkatkan aktivitas B elajar dan Hasil Belajar Siswa K elas V MI

Utomo Dananjaya, Media Pembelajaran Aktif. Bandung: Nuansa, 2011.

Wahidmurni,Dkk. EvaluasiPembelajaran.Yogyakarta:NuhaLitera, 2010.

Vol. 2 No. 1, Juli - Desember 2020

P - ISSN : 2715 - 7067

E - ISSN : 2720 - 8850 